\title{
Dynamic in vitro gastric digestion behavior of goat milk: Effects of homogenization and heat treatments
}

\author{
Siqi Li, $\odot$ Aiqian Ye, ${ }^{*} \odot$ Zheng Pan, $\odot$ Jian Cui, Anant Dave, and Harjinder Singh $\odot$ \\ Riddet Institute, Massey University, Private Bag 11 222, Palmerston North 4442, New Zealand
}

\begin{abstract}
The gastric digestion behavior of differently processed goat milks was investigated using a dynamic in vitro gastric digestion model, the human gastric simulator. Homogenization and heat treatment of goat milk resulted in gastric clots with highly fragmented structures. They also delayed the $\mathrm{pH}$ reduction during digestion, altered the chemical composition of the clots and the emptied digesta, promoted the release of calcium from the clots, and accelerated the hydrolysis and the emptying of milk proteins. The apparent density of the protein particles and the location of the homogenized fat globules changed during the digestion process, as shown in the emptied digesta of the homogenized goat milks. The effects of processing on the digestion behavior of goat milk were broadly similar to those previously reported for cow milk. However, the overall gastric digestion process of goat milk was more affected by homogenization than by heat treatments.
\end{abstract}

Key words: goat milk, heat treatment, homogenization, gastric digestion, protein hydrolysis

\section{INTRODUCTION}

Consumer interest in goat milk and its products has been growing in recent decades. The worldwide annual production of goat milk has increased by over $50 \%$ during the past 20 yr (Pulina et al., 2018; FAOSTAT, 2021). Goat milk provides an important source of nutrition for people living in developing and remote areas. Its perceived health benefits and the growing connoisseur interest in goat milk products have also promoted the growth in goat milk production and demand (Haenlein, 2004; Clark and Mora García, 2017; Roy et al., 2020).

Considerable research efforts into understanding the digestion behavior and the digestibility of ruminant milk have been made during recent decades. The most

Received July 7, 2021

Accepted October 15, 2021.

*Corresponding author: A.M.Ye@massey.ac.nz standout behavior during the digestion of cow milk is the formation of a coagulum, normally referred to as a "clot" or "curd," under gastric conditions (Huppertz and Chia, 2021; Li et al., 2021; Ye, 2021). This has been demonstrated both in vivo (Miranda and Pelissier, 1987; Ye et al., 2019b) and in in vitro studies employing (semi-)dynamic gastric digestion models (Ye et al., 2016a,b, 2017; Mulet-Cabero et al., 2019). During gastric digestion, the clot forms at a fairly high $\mathrm{pH}$ $(\sim 6.0)$ as a result of $\kappa$-casein hydrolysis by pepsin and the subsequent coagulation of the destabilized casein micelles, similar to the process of coagulation of milk by chymosin (Ye et al., 2016b; Mulet-Cabero et al., 2020b; Huppertz and Chia, 2021; Li et al., 2021; Ye, 2021). Previous studies have demonstrated that common processing treatments affect the gastric coagulation behavior of cow milk. Both homogenization and heat treatment resulted in clot structures that were looser and more open (Ye et al., 2017; Mulet-Cabero et al., 2019). In vivo studies demonstrated that intense heating of milk, such as UHT treatment, led to faster gastric digestion and emptying of the milk proteins (Miranda and Pelissier, 1987; Wada and Lönnerdal, 2014; Ye et al., 2019b).

Despite a similar macronutrient composition, goat milk has some different compositional and physicochemical characteristics compared with cow milk, which may affect its response to processing treatments, its digestion behavior, and their interactions. The content of $\alpha_{\mathrm{S1}^{-}}$casein in goat milk varies markedly with different genotypes and is generally lower than that of cow milk (Clark and Mora García, 2017; Hodgkinson et al., 2018; Verruck et al., 2019). The low $\alpha_{\mathrm{S} 1}$-casein concentration of goat milk has been suggested to be responsible for the weaker gels formed under acidification (Wang et al., 2019) and renneting (Ambrosoli et al., 1988). Other characteristics of goat milk that differ from those of cow milk include its higher content of medium-chain fatty acids, smaller fat globule size, larger casein micelle size, and higher ionic calcium concentration (Park et al., 2007; Claeys et al., 2014; Roy et al., 2020). It is not yet fully understood how the characteristics of goat milk interact with processing treatments and affect 
its gastric digestion behavior. For example, the heatinduced whey protein-casein micelle association, which has been attributed to the lower clot consistency in heated milk (Mulet-Cabero et al., 2019; Huppertz and Chia, 2021), has been reported to take place at a higher level in goat milk than in cow milk (Pesic et al., 2012).

Compared with the intensive studies on cow milk, the gastric digestion behavior of processed goat milk is less understood ( $\mathrm{Li}$ et al., 2021). Previous (semi-) dynamic in vitro studies found that gastric emptying and digestion of proteins were faster in infant formulas made from goat milk than in those made from cow milk (Maathuis et al., 2017; Ye et al., 2019a). A recent study showed that pasteurization had a greater effect in facilitating protein hydrolysis in goat milk than in cow milk (Roy et al., 2021a).

This study aimed to demonstrate the gastric digestion behaviors of differently processed goat milks in a dynamic gastric digestion system. The effects of homogenization and 2 types of heat treatment $\left(75^{\circ} \mathrm{C}\right.$ for $15 \mathrm{~s}$ and $95^{\circ} \mathrm{C}$ for $5 \mathrm{~min}$ ) were investigated. The compositions of the gastric clots and the emptied digesta were determined. The dynamics of clot breakdown, protein hydrolysis, and the release of proteins, peptides, fat, and calcium were also studied. The effects of processing on goat milk, compared with the effects on cow milk in previous studies, are discussed.

\section{MATERIALS AND METHODS}

\section{Materials}

Fresh raw goat milk was provided by Cilantro Cheese Ltd. (Hamilton, New Zealand) and was processed in the FoodPilot (Massey University, Palmerston North, New Zealand). Four differently processed goat milks were used in the digestion experiment: raw milk (RM), pasteurized milk (PM; $75^{\circ} \mathrm{C}$ for $\left.15 \mathrm{~s}\right)$, homogenized pasteurized milk (HPM; 20 and $5 \mathrm{MPa}, 75^{\circ} \mathrm{C}$ for $15 \mathrm{~s}$ ), and homogenized heated milk (HHM; 20 and $5 \mathrm{MPa}$, $95^{\circ} \mathrm{C}$ for $\left.5 \mathrm{~min}\right)$. The pasteurization was performed on a tubular indirect UHT plant (Massey University, Palmerston North, New Zealand). The homogenization was carried out in a 2-stage homogenizer at $20 \mathrm{MPa}$ in the first stage and $5 \mathrm{MPa}$ in the second stage. A portion of homogenized goat milk was heated in the UHT plant to $95^{\circ} \mathrm{C}$ and held in an external water bath at $95^{\circ} \mathrm{C}$ for 5 min. Following the heat treatments, the processed milks were cooled rapidly to $20^{\circ} \mathrm{C}$ using either the cooling function of the UHT plant or an ice water bath. Sodium azide $(0.02 \% \mathrm{wt} / \mathrm{wt})$ was added to the milk samples for preservation before further analysis.

Three different batches of goat milk (10 L each) were sampled, processed, and used for the digestion experiment from November 2019 to February 2020. The macronutrient composition of the milk was determined using a MilkoScan FT1 (Foss Electric). The total calcium concentrations of the milk samples were determined using inductively coupled plasma-optical emission spectrometry following digestion with nitric and hydrochloric acids. The fat globule size of the goat milk was determined on a MasterSizer 2000 (Malvern Instruments Ltd.), as described in Li et al. (2019), after dissociating the casein micelles.

\section{Dynamic Gastric Digestion}

The gastric digestion was carried out using a human gastric simulator (Kong and Singh, 2010). A protocol that harmonized previous methods using the human gastric simulator (Ye et al., 2016a, 2017) and the INFOGEST recommendations (Brodkorb et al., 2019; Mulet-Cabero et al., 2020a) was developed.

The electrolyte compositions of the simulated salivary fluid (SSF) and the simulated gastric fluid (SGF) were prepared as described by Brodkorb et al. (2019). The oral phase of digestion was performed by mixing $24 \mathrm{~g}$ of SSF into $200 \mathrm{~g}$ of goat milk, equal to the solids content of the milk (Mulet-Cabero et al., 2020a). Amylase was not added to the SSF because of the absence of starch in the sample. A $1.25 \times$ concentrated electrolyte SGF was prepared and adjusted to $\mathrm{pH}$ 1.5. During the digestion, the electrolyte SGF, pepsin (P7000, determined pepsin activity $550 \mathrm{U} / \mathrm{mg}$, Sigma-Aldrich), and $\mathrm{CaCl}_{2}$ solution were gradually added and the correct composition of the final SGF was obtained. The pepsin activity in the final SGF was $2,000 \mathrm{U} / \mathrm{mL}$. Before the start of the gastric phase, $20 \mathrm{~mL}$ of SGF (1×, including pepsin) was added to the milk-SSF mixture as the basal level in the fasted state. The digestion was conducted for 240 min at $37^{\circ} \mathrm{C}$. The human gastric simulator simulated the peristaltic movement in the stomach chamber at a frequency of 3 times per minute. The addition rate of SGF was $2.5 \mathrm{~mL} / \mathrm{min}$ and the digesta were emptied every $20 \mathrm{~min}(3 \mathrm{~mL} / \mathrm{min})$ through a $1-\mathrm{mm}$ sieve to mimic gastric sieving. From preliminary trials, we found that raw goat milk digested under these conditions would reach pH 2.0 toward the end of the $240 \mathrm{~min}$ of digestion time, aligning with that recommended by Mulet-Cabero et al. (2020a).

The clots and the emptied digesta were sampled at 20, 60, 120, 180, and $240 \mathrm{~min}$ of digestion for further analysis. To sample the clots at different time points, the digestion experiment of each sample was performed for the 5 different durations mentioned above. The clots were taken by passing the content in the gastric chamber through a 1-mm sieve and collecting the solid part on the sieve. The surface of the clots was rinsed with 
reverse osmosis water to remove the attaching enzyme. Part of each clot sample was heated in boiling water for 5 min to inactivate the pepsin, before being freeze-dried and ground into a powder for further compositional analysis. Because of the limited amount of clot available for some milk samples at 240 min of digestion, the compositional analyses (fat, CP, calcium, and gel electrophoresis) of the clots were conducted until 180 min. The emptied digesta samples collected for compositional analysis were heated in boiling water for $5 \mathrm{~min}$ to inactivate the pepsin and were stored at $-20^{\circ} \mathrm{C}$.

\section{Characterization of Digestion Samples}

$p H$ Profiles. The $\mathrm{pH}$ profiles during the digestion were determined using a CyberScan pH 510 (Eutech Instruments) every $20 \mathrm{~min}$ by measuring the freshly emptied digesta.

Macro- and Microstructures. To compare the macrostructures of the clots and the digesta, photographs of the fresh clots and the digesta samples were taken. Confocal laser scanning microscopy imaging of the fresh clots and the digesta samples was performed as described in Ye et al. (2017). In the confocal images, the proteins are presented in green and the lipids are presented in red.

Clot Weights. The wet weight of the clots was determined immediately after sampling. For dry weight determination, each clot was mixed well with a spatula before a portion was taken, weighed when wet, and weighed again after oven drying at $105^{\circ} \mathrm{C}$ for $24 \mathrm{~h}$. The dry weight of the whole clot was then corrected based on the wet weight ratio between the whole clot and the portion taken for oven drying.

Chemical Compositions of Clots and Emptied Digesta. The fat contents of the freeze-dried clots and the digesta samples were analyzed using the Mojonnier method (Ye et al., 2017). The CP contents of the dry clots and the digesta were determined using the Dumas method (method 968.06, AOAC International, 2016; protein conversion factor $=6.38$ ). It should be noted that the CP content determined using the Dumas method includes the peptides formed during digestion.

The calcium contents of the freeze-dried clots were determined using the same method as described above. To indicate the gradual release of calcium from the clots during digestion, the amounts of calcium that are associated with the clots are presented as their proportions in the amount of total calcium in $200 \mathrm{~g}$ of goat milk.

Protein Profiles and Hydrolysis in Clots and Emptied Digesta. SDS-PAGE was used to analyze the protein composition and the extent of protein hydrolysis in the freeze-dried clot powders and the di- gesta. The samples were diluted in SDS-PAGE sample buffer to reach a final CP concentration of $1 \mathrm{mg} / \mathrm{mL}$. Precision Plus Protein Dual Xtra Prestained Protein Standard (2-250 kDa, Bio-Rad Laboratories) was used as a molecular weight marker. Raw skim goat milk was used as a control sample.

Glycine SDS-PAGE of both the clots and the digesta was performed under reducing conditions on Criterion Tris-HCl 10-20\% precast gels (Bio-Rad) following the manufacturer's instructions. The glycine SDS-PAGE gels were stained with Coomassie Brilliant Blue R-250.

For better visualization of small peptides, the digesta samples were also analyzed with tricine SDS-PAGE on $16 \%$ acrylamide gels using a Bio-Rad Mini-Protean system (Bio-Rad Laboratories). The gel preparation and the electrophoresis were performed as described by Schägger (2006) and the fixing, staining, and destaining procedures reported by Haider et al. (2012) were used.

A Gel Doc XR+ system and Image Lab 5.2.1 software (Bio-Rad Laboratories) were used to scan all SDSPAGE gels.

\section{Statistical Analysis}

Statistical analysis was conducted with Minitab 19 (Minitab Inc.) statistical software. All measurements were performed in triplicate with 3 different batches of milk. One-way ANOVA with Tukey's post-hoc test and the $t$-test were used to determine significant differences between different processing groups. Error bars in figures and the values following means and \pm indicate standard deviations.

\section{RESULTS}

\section{Milk Characterization}

On average, the goat milk samples contained $3.06 \pm$ $0.06 \mathrm{~g} / 100 \mathrm{~g}$ of protein, $3.34 \pm 0.18 \mathrm{~g} / 100 \mathrm{~g}$ of fat, 4.26 $\pm 0.02 \mathrm{~g} / 100 \mathrm{~g}$ of lactose, and $0.110 \pm 0.003 \mathrm{~g} / 100 \mathrm{~g}$ of total calcium. The mean fat globule sizes $\left(D_{4,3} \pm \mathrm{SD}\right)$ of the RM, PM, HPM, and HHM goat milk samples were $3.82 \pm 0.14,3.99 \pm 0.45,0.72 \pm 0.11$, and $0.71 \pm$ $0.15 \mu \mathrm{m}$.

\section{pH Profiles}

Figure 1 shows the changing $\mathrm{pH}$ profiles of the differently processed goat milk digesta over $240 \mathrm{~min}$ of gastric digestion. The $\mathrm{pH}$ of $\mathrm{RM}$ decreased rapidly to $2.76 \pm 0.10$ during the first $120 \mathrm{~min}$ of digestion and then slowly reached a final $\mathrm{pH}$ of $2.03 \pm 0.01$ at 240 min. The $\mathrm{pH}$ of PM followed a similar trend to that of RM during digestion. From 80 to $240 \mathrm{~min}$, the $\mathrm{pH}$ of 


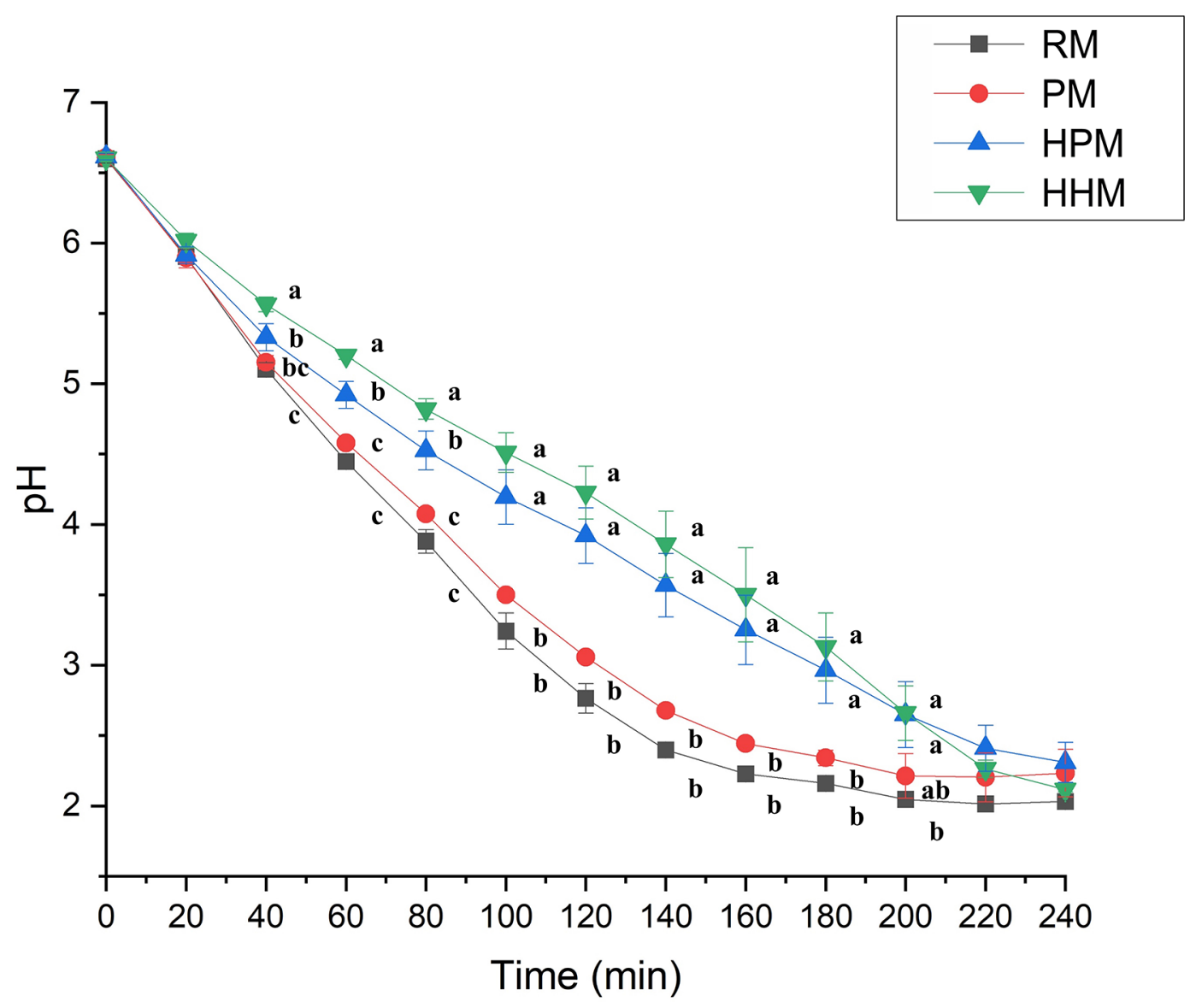

Figure 1. pH profiles of processed goat milk during dynamic gastric digestion $(\mathrm{n}=3)$. Different letters $(\mathrm{a}-\mathrm{c})$ indicate significant differences between different processed samples at each time point $(P<0.05)$. RM $=$ raw milk; $\mathrm{PM}=$ pasteurized milk $\left(75^{\circ} \mathrm{C}\right.$ for $\left.15 \mathrm{~s}\right) ; \mathrm{HPM}=$ homogenized pasteurized milk (20 and $5 \mathrm{MPa}, 75^{\circ} \mathrm{C}$ for $\left.15 \mathrm{~s}\right)$; HHM $=$ homogenized heated milk $\left(20\right.$ and $5 \mathrm{MPa}, 95^{\circ} \mathrm{C}$ for 5 min). Error bars indicate SD.

the PM digesta was 0.2 to 0.3 units higher than that of the RM digesta. In contrast to the nonhomogenized goat milk digesta, the HPM and HHM digesta had delayed $\mathrm{pH}$ reductions during the early to mid-stages of digestion, resulting in near-linear $\mathrm{pH}$ curves over the $240 \mathrm{~min}$ of digestion. In particular, the $\mathrm{pH}$ of the HHM digesta had the slowest reduction among all samples until 180 min of digestion but decreased at the highest rate from 180 to $240 \mathrm{~min}$, resulting in a final $\mathrm{pH}$ of $2.12 \pm 0.02$, lower than those of the PM and HPM digesta.

\section{Macro- and Microstructures of Gastric Clots}

The effects of processing on the macro- and microstructures of the clots formed during the gastric digestion of goat milk are presented in Figure 2. The RM and PM clots were intact with fairly smooth surfaces. In contrast, the clots of the homogenized goat milks (HPM and HHM) were very crumbly, having a wet and soft appearance similar to that of cottage cheese. In particular, the HHM clots appeared to be more fragmented with smaller granules than the HPM clots.

The microstructure of the clots was also greatly affected by homogenization (Figure 2). The RM clot had a compact structure with fat globules embedded inside and clear signs of coalescence. A similar structure was observed for the PM clot, with some gaps in the matrix. The homogenized goat milk clots had more open and porous structures. Small fat droplets were more evenly distributed in the homogenized milk clot matrices, with signs of coalescence inside and around the protein network. Consistent with the macrostructures, the microstructure of the HHM clot was more loose and porous than that of the HPM clot, with smaller continuous solid structures surrounded by more and larger gaps.

\section{Clot Weights and Compositions}

The wet and dry weights of the clots are presented in Figure 3. At the beginning of the digestion, the wet weight of the clots followed the order of HHM > HPM 
$>\mathrm{PM}$ and RM; this reversed in the last 60 to $120 \mathrm{~min}$ of digestion (Figure 3A). On a DM basis (Figure 3B), the clot weights of the differently processed milks did not vary significantly $(P>0.05)$ during the first $60 \mathrm{~min}$ of digestion. The dry weights of the homogenized milk clots, particularly HHM, decreased more rapidly during the digestion process than those of RM and PM. From 20 to 240 min of digestion, the mean decreases in the dry weights of the clots were $22.5,50.1,81.9$, and $97.5 \%$ for RM, PM, HPM, and HHM, respectively.

Figure $4 \mathrm{~A}$ shows the mean proportions of $\mathrm{CP}$ and fat in the goat milk clots on a DM basis. The RM clots contained approximately $45 \%$ fat and $40 \%$ protein, which remained constant during digestion. Similarly, the PM clots had stable compositions over time but had somewhat lower proportions of CP than the RM clots. Homogenization resulted in a few differences in the composition of the clots. First, solids other than CP and fat made up a higher proportion of the homogenized goat milk clots $(23.3 \%)$ than of the nonhomogenized milk clots $(15.2 \%)$. These unidentified solids were probably lactose and minerals. Second, the proportions of fat were lower in the homogenized milk clots than in the nonhomogenized milk clots in the early stages of digestion. Finally, the proportion of fat in the homogenized milk clots increased from 120 min of digestion. This change over time was particularly pronounced in the HHM clots.

Figure 4B shows the percentage (wt/wt \%) of calcium present in the clot DM. The RM clots retained the highest amount of calcium, followed by the PM clots and then the homogenized milk clots. The percentages of goat milk calcium that were present in the clots at 20, 60, and 180 min of digestion are shown in Figure $4 \mathrm{C}$. At 20 min of digestion, the clots formed in all the processed milks contained approximately $50 \%$ of the total calcium in the goat milk. Subsequently, the release of calcium from the clot was faster in the homogenized milk clots than in their nonhomogenized counterparts $(P=0.01)$. After $180 \mathrm{~min}$ of digestion, the proportions of total calcium remaining in the gastric clots were 36.3 $\pm 6.4,25.2 \pm 9.9,9.0 \pm 1.0$, and $4.9 \pm 0.7 \%$ for RM, PM, HPM, and HHM, respectively.

\section{Macro- and Microstructures of Emptied Digesta}

Figure 5 presents confocal images of the emptied digesta during the digestion process. For the nonho-
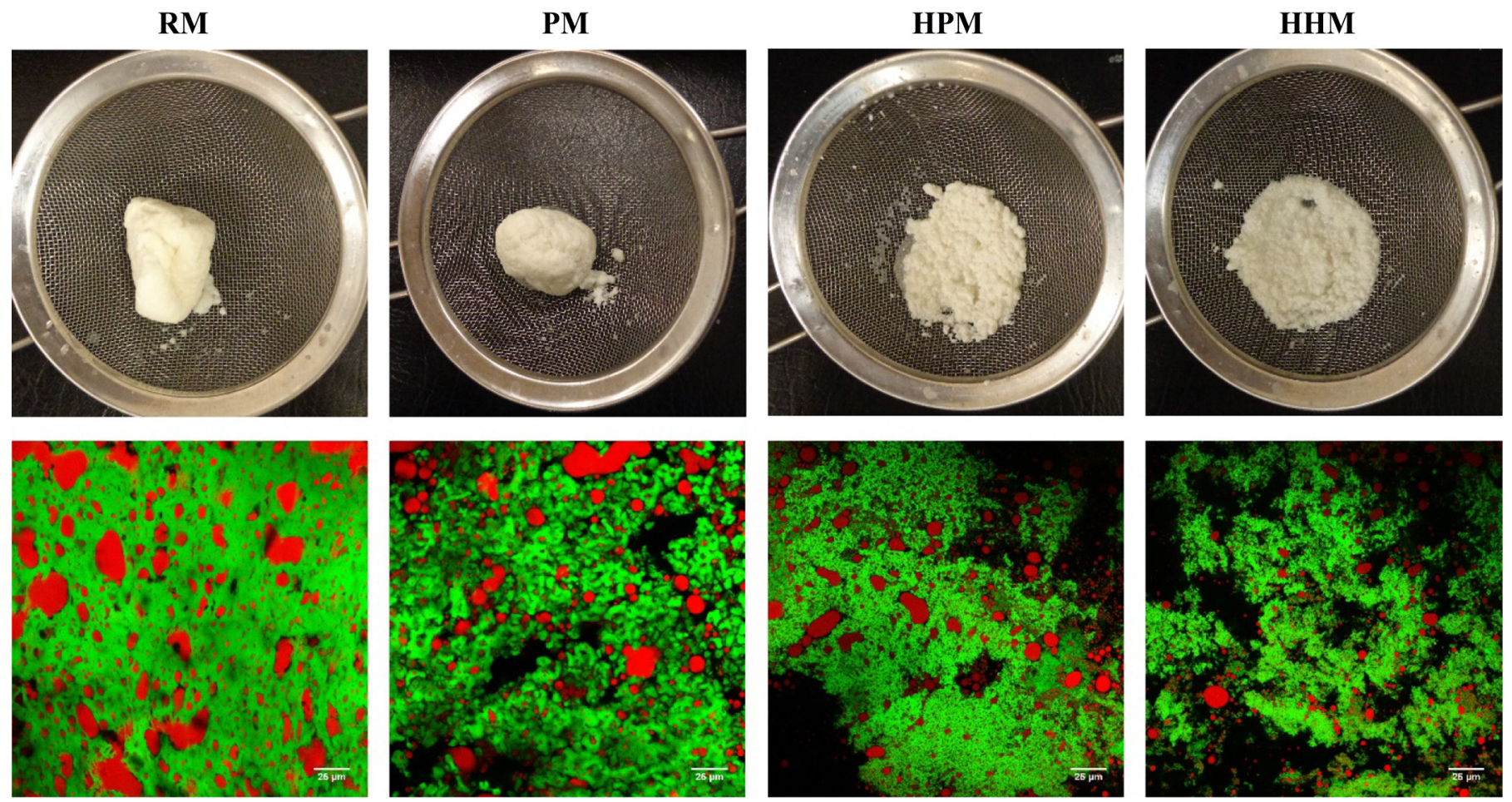

Figure 2. Photographs and confocal micrographs of gastric clots formed by differently processed goat milks (180 min of digestion). In the confocal micrographs, green and red represent proteins and lipids, respectively. Scale bars indicate $25 \mu \mathrm{m}$. RM $=\mathrm{raw}$ milk; PM $=$ pasteurized milk $\left(75^{\circ} \mathrm{C}\right.$ for $\left.15 \mathrm{~s}\right) ; \mathrm{HPM}=$ homogenized pasteurized milk $\left(20\right.$ and $5 \mathrm{MPa}, 75^{\circ} \mathrm{C}$ for $\left.15 \mathrm{~s}\right) ; \mathrm{HHM}=$ homogenized heated milk $(20$ and $5 \mathrm{MPa}$, $95^{\circ} \mathrm{C}$ for $\left.5 \mathrm{~min}\right)$. 

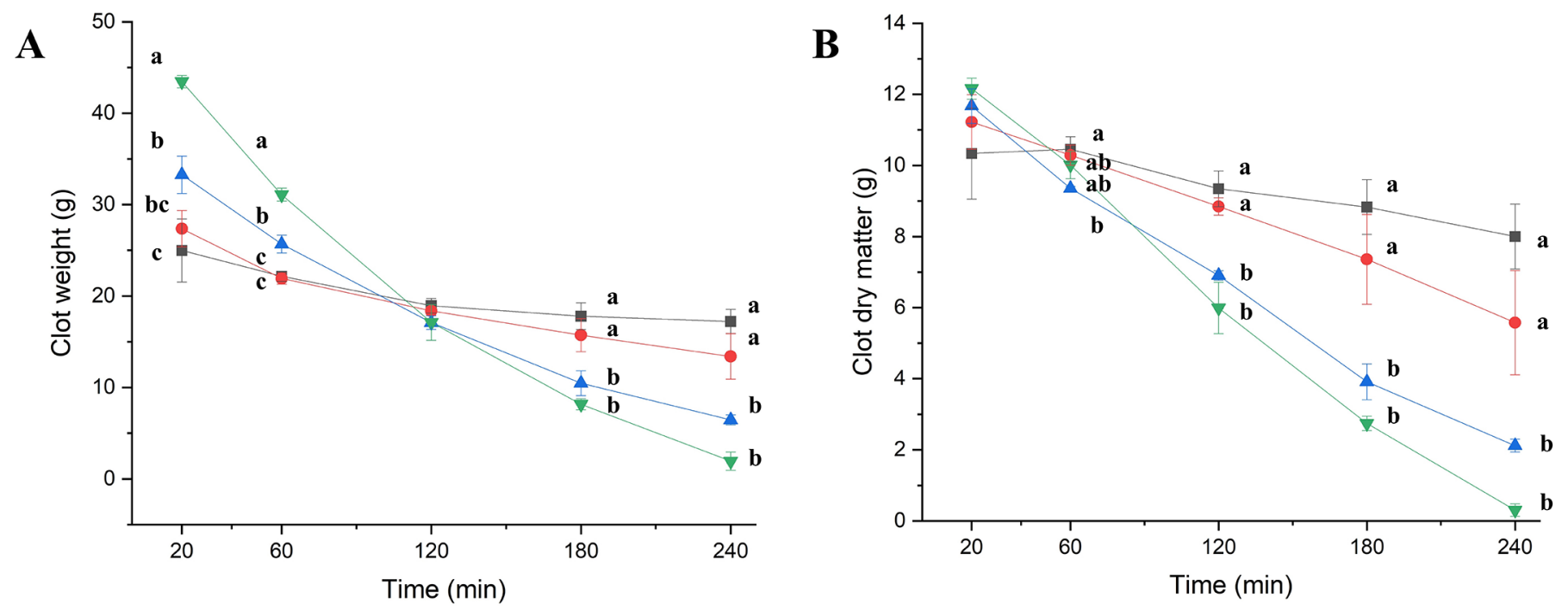

Figure 3. Wet weight (A) and dry weight (B) of fresh clots formed during the gastric digestion of RM (ם), PM $(\bullet)$, HPM $(\boldsymbol{\Delta})$, and HHM $(\boldsymbol{\nabla}) ; \mathrm{n}=3$. Different letters $(\mathrm{a}-\mathrm{c})$ indicate significant differences between different processed samples at each time point $(P<0.05)$. RM $=$ raw milk; $\mathrm{PM}=$ pasteurized milk $\left(75^{\circ} \mathrm{C}\right.$ for $\left.15 \mathrm{~s}\right) ; \mathrm{HPM}=$ homogenized pasteurized milk $\left(20\right.$ and $5 \mathrm{MPa}, 75^{\circ} \mathrm{C}$ for $\left.15 \mathrm{~s}\right) ; \mathrm{HHM}=$ homogenized heated milk (20 and $5 \mathrm{MPa}, 95^{\circ} \mathrm{C}$ for $5 \mathrm{~min}$ ). Error bars indicate SD.

mogenized goat milks, native milk fat globules were observed throughout the digestion process, although they appeared to be diluted over time. At 120 and 240 min, some protein aggregates were found to be attached to or connected to the fat globules, which was not observed in the first $60 \mathrm{~min}$ of digestion. In contrast to the nonhomogenized milks, the protein and the fat globules in the emptied digesta of the homogenized milks were present in very different structures, which also evolved during the digestion process. At 20 min of digestion, a small number of protein particles with embedded fat globules were present in the digesta of HPM and HHM. From 60 min onward, a large number of small particles were emptied. Particles similar to or larger than 25 $\mu \mathrm{m}$ became more abundant in the digesta during the later stages of gastric digestion. In addition, in the first 60 min of digestion, many homogenized fat globules were individually dispersed in the digesta of HPM and HHM (Figure 5). However, from 120 min of digestion, these individual homogenized fat globules were far less abundant. Interestingly, the color of the protein particles appeared to be more red during the later stages of digestion.

To further demonstrate the physical properties of the structures in the emptied digesta of the homogenized goat milks, photographs of HPM and HHM digesta samples are presented in Figure 6. At 20 min of digestion, sedimenting particles were found in the digesta, and were more abundant for HHM. From 60 min on- ward, fewer sedimenting particles were found, whereas floating particles appeared and became more abundant over time. The HHM digesta contained greater amounts of these floating particles than their HPM counterparts.

\section{Compositions of Emptied Digesta}

Figure 7 shows the fat and $\mathrm{CP}$ contents of the digesta emptied at different time points. The RM and PM digesta contained similar amounts of fat during the digestion process, with a slightly decreasing trend during the first 120 to $180 \mathrm{~min}$. At $240 \mathrm{~min}$ of digestion, the PM digesta had an increase in its fat concentration. The protein concentrations followed a similar trend to the fat concentrations for the nonhomogenized goat milks (Figure 7B), with slightly greater reductions during the first $120 \mathrm{~min}$. The homogenized milk digesta had similar fat and protein concentrations during the first 60 min of digestion. From 60 to 240 min, the concentrations of fat in the HPM and HHM digesta increased continuously, the extent of which was greater for the HHM digesta. Concurrently, the protein content in the homogenized milk digesta increased from 60 to 120 or $180 \mathrm{~min}$ and then decreased again. From $120 \mathrm{~min}$ of digestion, the homogenized milk digesta contained significantly higher amounts of fat and protein than their nonhomogenized counterparts $(P<0.01)$. The fat-toprotein ratios in the emptied digesta samples are presented in Figure 7C. The homogenized milk digesta had 

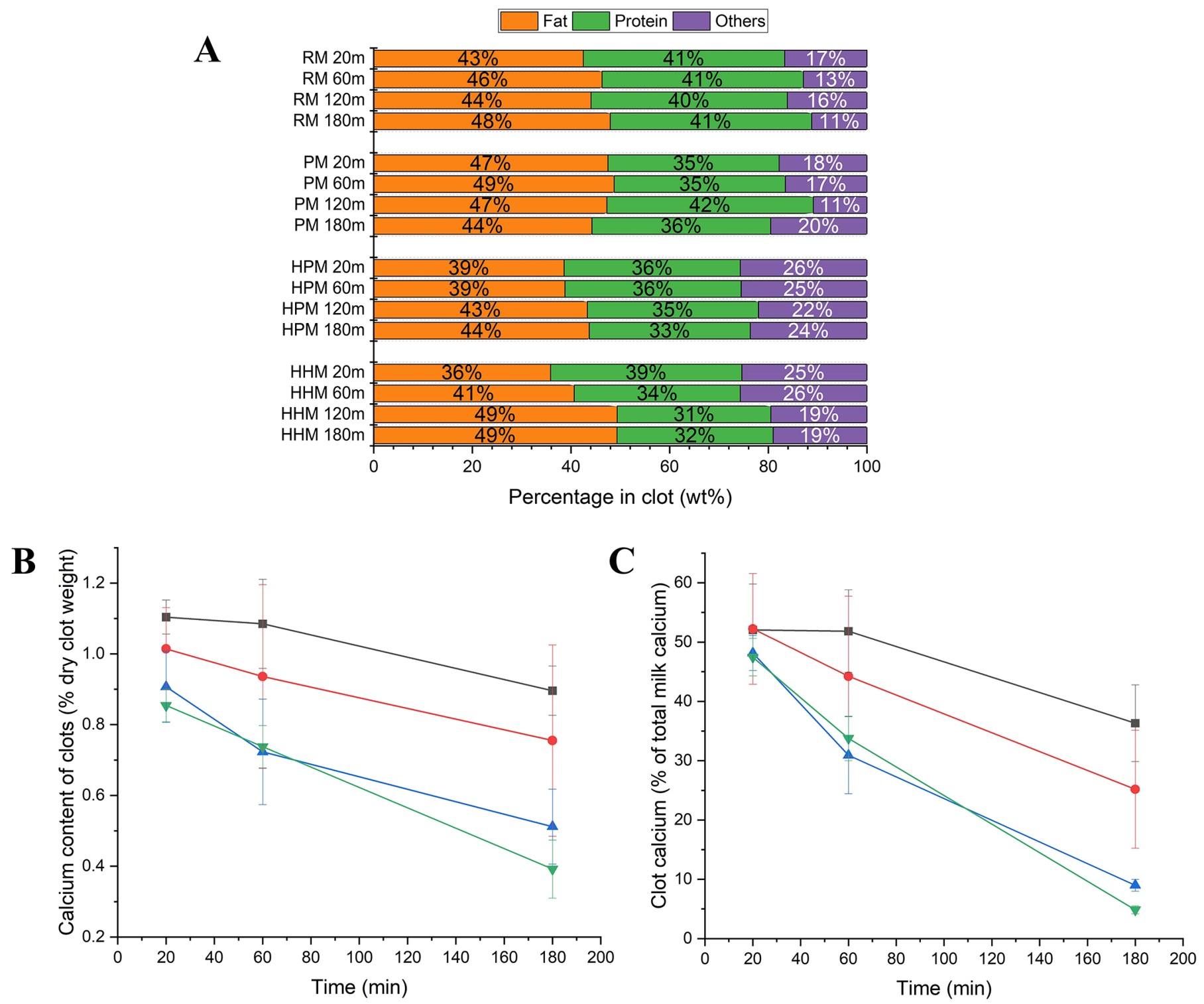

Figure 4. Chemical composition of gastric clots on a DM basis (A, fat and CP; B, calcium) and the proportion of clot calcium in the total

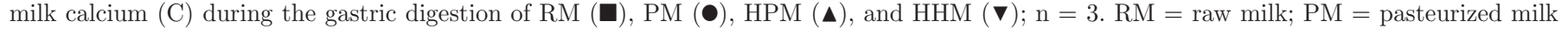
$\left(75^{\circ} \mathrm{C}\right.$ for $\left.15 \mathrm{~s}\right) ; \mathrm{HPM}=$ homogenized pasteurized milk $\left(20\right.$ and $5 \mathrm{MPa}, 75^{\circ} \mathrm{C}$ for $\left.15 \mathrm{~s}\right) ; \mathrm{HHM}=$ homogenized heated milk $\left(20\right.$ and $5 \mathrm{MPa}, 95^{\circ} \mathrm{C}$ for $5 \mathrm{~min})$. Error bars indicate SD.

elevated fat-to-protein ratios from 180 min of digestion $(P<0.01)$, whereas the ratios did not vary significantly for the nonhomogenized milk digesta.

\section{Protein Profiles of Clots and Emptied Digesta}

Figure 8 presents the protein profiles of the clots at different time points, visualized using SDS-PAGE. The composition of the major milk proteins in the clots was rather stable during the digestion of the nonhomogenized goat milks (RM and PM). The clots were composed mainly of caseins and a band at $\sim 14 \mathrm{kDa}$, the proportions of which did not appear to change much during digestion (Figure 8). The major whey proteins $\beta-\mathrm{LG}$ and $\alpha-\mathrm{LA}$ were also found in small amounts. Two bands at $\sim 18 \mathrm{kDa}$, presumably caseinderived peptides, were present in the clots in increasing amounts over the digestion period. Compared with the RM clots, the PM clots contained slightly greater proportions of whey proteins and the peptides at $\sim 18$ $\mathrm{kDa}$. In addition, traces of peptides at $\sim 15$ and $\sim 10$ $\mathrm{kDa}$ were also observed at 120 and $180 \mathrm{~min}$ of digestion in the PM clot; they were nearly absent in the RM clot. 

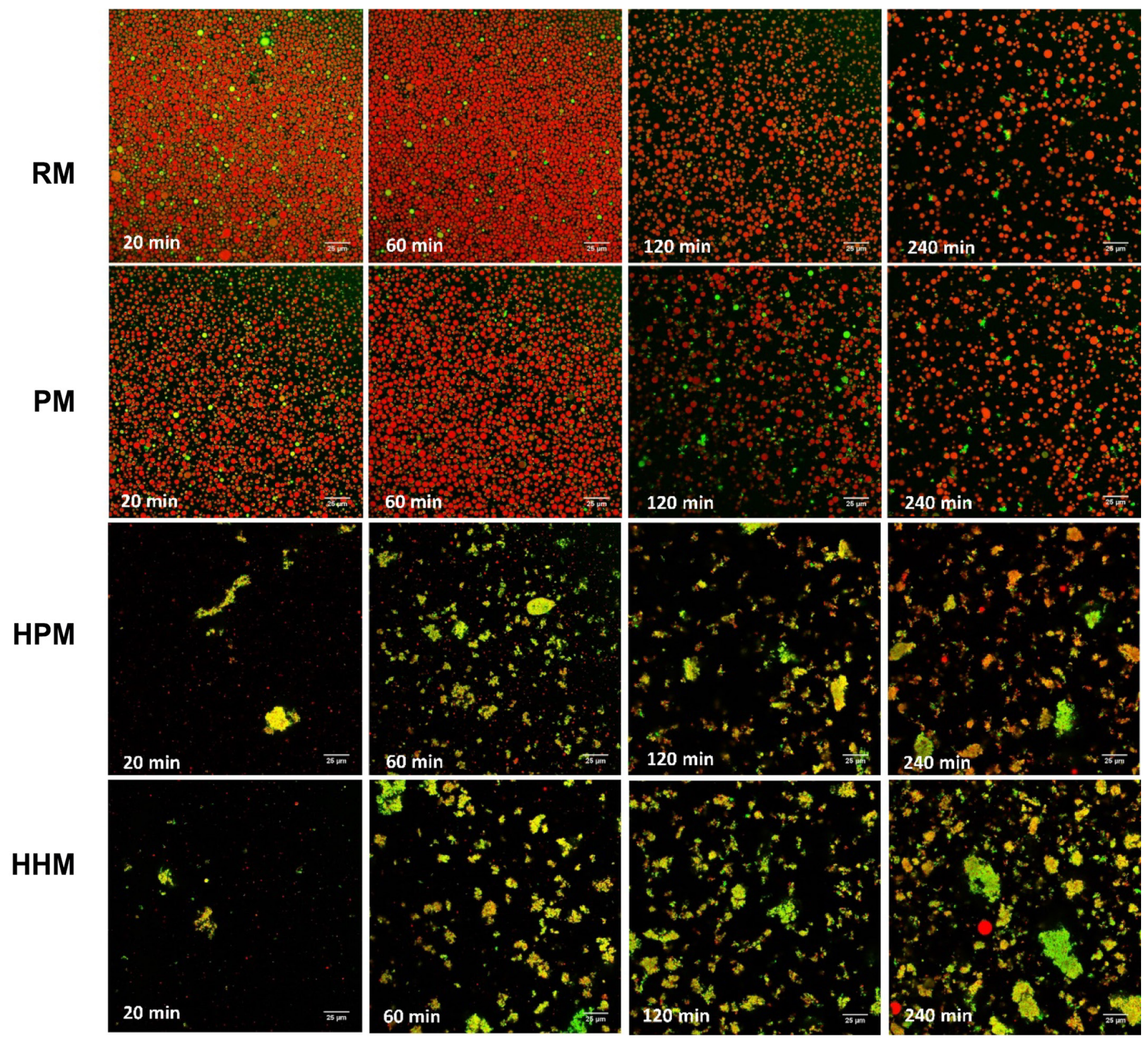

Figure 5. Confocal micrographs of emptied digesta during gastric digestion. Green and red represent proteins and lipids, respectively. Scale bars indicate $25 \mu \mathrm{m} . \mathrm{RM}=$ raw milk; $\mathrm{PM}=$ pasteurized milk $\left(75^{\circ} \mathrm{C}\right.$ for $\left.15 \mathrm{~s}\right) ; \mathrm{HPM}=$ homogenized pasteurized milk $\left(20\right.$ and $5 \mathrm{MPa}, 75^{\circ} \mathrm{C}$ for $15 \mathrm{~s}) ; \mathrm{HHM}=$ homogenized heated milk $\left(20\right.$ and $5 \mathrm{MPa}, 95^{\circ} \mathrm{C}$ for $\left.5 \mathrm{~min}\right)$.

Unlike the nonhomogenized milk clots, the protein compositions of the HPM and HHM clots changed markedly during digestion (Figure 8). The decrease in the intensity of the casein bands during digestion was very pronounced. The proportions of peptides at $\sim 18$ $\mathrm{kDa}$ were greater in the HPM and HHM clots than in their nonhomogenized counterparts; they peaked at 60 to $120 \mathrm{~min}$ of digestion and then decreased during further digestion. The band at $\sim 14 \mathrm{kDa}$ also decreased in intensity during the later stages of digestion. In addition, the peptide bands at $\sim 15 \mathrm{kDa}$ and below $\sim 10$ $\mathrm{kDa}$ during the later stages of digestion were more abundant in the homogenized milk clots than in the nonhomogenized milk clots. The HHM clot contained greater amounts of $\beta$-LG and $\alpha$-LA than all other clots. Compared with HPM goat milk, the intense heating $\left(95^{\circ} \mathrm{C}\right.$ for $\left.5 \mathrm{~min}\right)$ of HHM goat milk resulted in more rapid digestion of the caseins in the clots. In addition, 

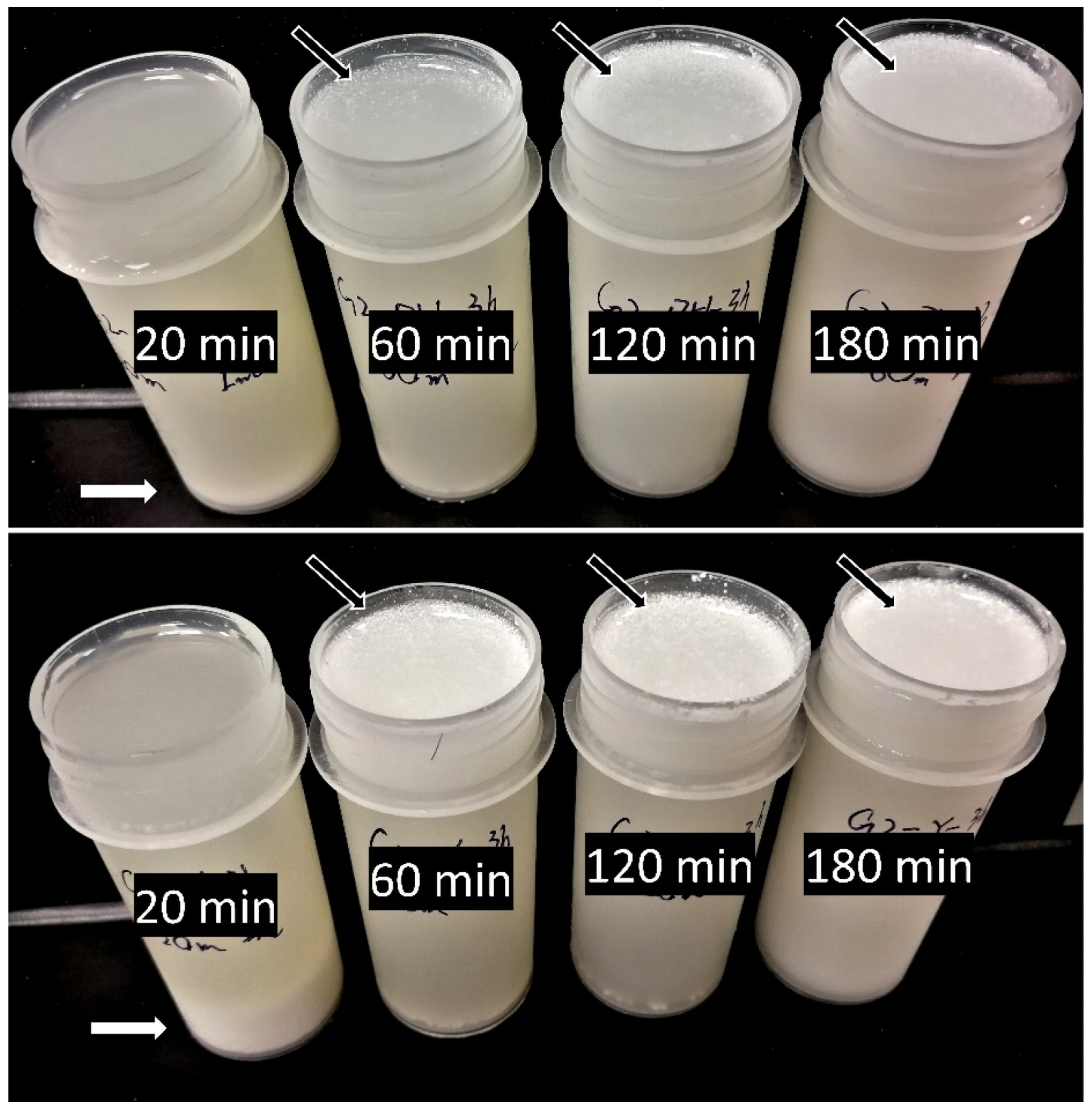

Figure 6. Photographs of emptied digesta of HPM (top) and HHM (bottom). Black arrows indicate floating particles; white arrows indicate sedimenting particles. $\mathrm{HPM}=$ homogenized pasteurized milk $\left(20\right.$ and $5 \mathrm{MPa}, 75^{\circ} \mathrm{C}$ for $\left.15 \mathrm{~s}\right) ; \mathrm{HHM}=$ homogenized heated milk $(20$ and $5 \mathrm{MPa}$, $95^{\circ} \mathrm{C}$ for $\left.5 \mathrm{~min}\right)$.

the HHM clots also showed greater degradation of $\beta$-LG and the peptides at $\sim 18, \sim 15, \sim 14 \mathrm{kDa}$, and below $\sim 10$ $\mathrm{kDa}$ at $180 \mathrm{~min}$ of digestion.

Figure 9 shows the SDS-PAGE profiles of the emptied digesta. The RM and PM digesta had almost identical protein profiles (Figure 9A). Caseins were not observed from 20 min of digestion, presumably because clot formation depleted free caseins in the aqueous phase. $\beta$-Lactoglobulin was abundant in the digesta early on, the intensity of which decreased gradually over time. 

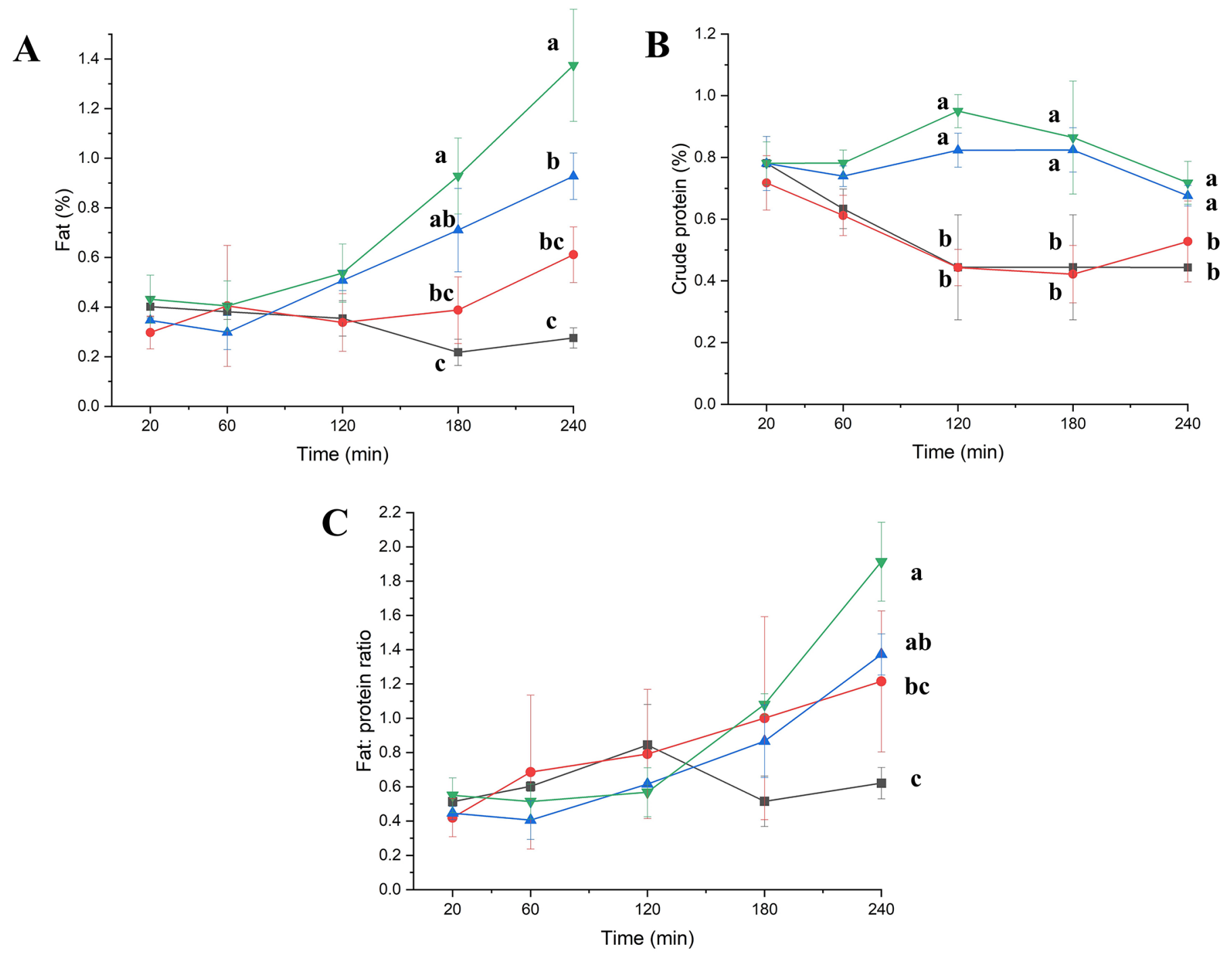

Figure 7. Concentrations of fat (A) and $\mathrm{CP}(\mathrm{B})$ and fat-to-protein ratio $(\mathrm{C})$ of emptied digesta formed during the gastric digestion of RM $(\boldsymbol{\square})$, PM $(\bullet)$, HPM $(\boldsymbol{\Delta})$, and HHM ( $\boldsymbol{\nabla}) ; \mathrm{n}=3$. Different letters $(\mathrm{a}-\mathrm{c})$ indicate significant differences between different processed samples at each time point $(P<0.05) . \mathrm{RM}=$ raw milk; $\mathrm{PM}=$ pasteurized milk $\left(75^{\circ} \mathrm{C}\right.$ for $\left.15 \mathrm{~s}\right) ; \mathrm{HPM}=$ homogenized pasteurized milk $\left(20\right.$ and $5 \mathrm{MPa}, 75^{\circ} \mathrm{C}$ for $15 \mathrm{~s}) ; \mathrm{HHM}=$ homogenized heated milk $\left(20\right.$ and $5 \mathrm{MPa}, 95^{\circ} \mathrm{C}$ for $\left.5 \mathrm{~min}\right)$. Error bars indicate SD.

This was consistent with previous studies on cow milk; that is, native $\beta$-LG resists hydrolysis by pepsin and the dilution effect in a dynamic digestion system causes the reduction in its concentration (Ye et al., 2016b). $\alpha$-Lactalbumin was abundant in the digesta at 20 and $60 \mathrm{~min}$ but disappeared completely from $120 \mathrm{~min}$ of digestion.

The proportions of $\beta-\mathrm{LG}$ in the HPM emptied digesta appeared to be lower than those in the nonhomogenized digesta and also decreased more rapidly over time (Figure 9A). A faint $\alpha$-LA band was visible at 120 min of digestion, in contrast to the nonhomogenized milk digesta. The HHM digesta had the most standout protein profile (Figure 9A). At $20 \mathrm{~min}$, a considerable amount of intact caseins had been emptied, along with some peptides at $\sim 18$ and $\sim 14 \mathrm{kDa}$ that were present in the clots (Figure 8). The proportions of whey proteins in the HHM digesta, particularly $\beta-\mathrm{LG}$, were much lower than those in the other digesta. $\alpha$-Lactalbumin was evident until 120 min of digestion, as with the HPM digesta.

Peptides smaller than $10 \mathrm{kDa}$ were visualized in the digesta using tricine SDS-PAGE, as shown in Figure 9B. For RM and PM, the staining intensity of the peptide bands of 4 to $6 \mathrm{kDa}$ gradually grew during digestion. These peptide bands were more abundant in the HPM and HHM digesta than in the nonhomogenized digesta at 60 min of digestion. In addition, the peptide 
band at $6 \mathrm{kDa}$ was more abundant in the homogenized milk digesta than in the RM and PM digesta from 60 to $180 \mathrm{~min}$. At $240 \mathrm{~min}$ of digestion, the band at $6 \mathrm{kDa}$ decreased markedly in intensity in the HPM and HHM digesta and the band below $5 \mathrm{kDa}$ became the most dominant.

\section{DISCUSSION}

\section{Effect of Processing on Clot Structure and $\mathrm{pH}$ Profiles}

Heat treatment and, more so, homogenization resulted in fragmented structures of the gastric clots (Figure 2). The loosening effect of heat treatment on clot structures has been attributed to the incorporation of the heat-denatured whey proteins, which may weaken the casein-casein and casein-fat globule interactions (Ye et al., 2019b). Homogenization results in the association of some casein micelles with the homogenized fat globules and their spreading around the surface of the fat globules (Sharma et al., 1996). This will reduce the surface area of the casein micelles that is available for pepsin-induced coagulation and will interfere with the further fusing of adjacent caseins into a firm and continuous network. In addition, more fat globules are incorporated into the clots of homogenized milk, which may reduce their consistency (Mulet-Cabero et al., 2019) and render them more susceptible to disintegration under gastric contractions.

Homogenization and heat treatment reduced the rate of $\mathrm{pH}$ reduction during dynamic gastric digestion (Figure 1). This effect was probably connected to the formation and breakdown of the clots in the stomach (Figure 2). Caseins, with their associated micellar calcium phosphates, contribute the most to the buffering capacity of milk (Salaün et al., 2005). Raw goat milk formed firm and intact clots that effectively depleted caseins in the aqueous phase, as indicated by the protein composition of the digesta (Figure 9A). When more intense processing conditions were applied, the clots that formed became more fragmented and the greater amounts of dispersed buffering components readily resisted the $\mathrm{pH}$ reduction caused by the addition of SGF. In addition, the fragmented structures of the clots would also improve the accessibility to pepsin and promote the formation of peptides, which also contribute to increasing the buffering capacity. The effects

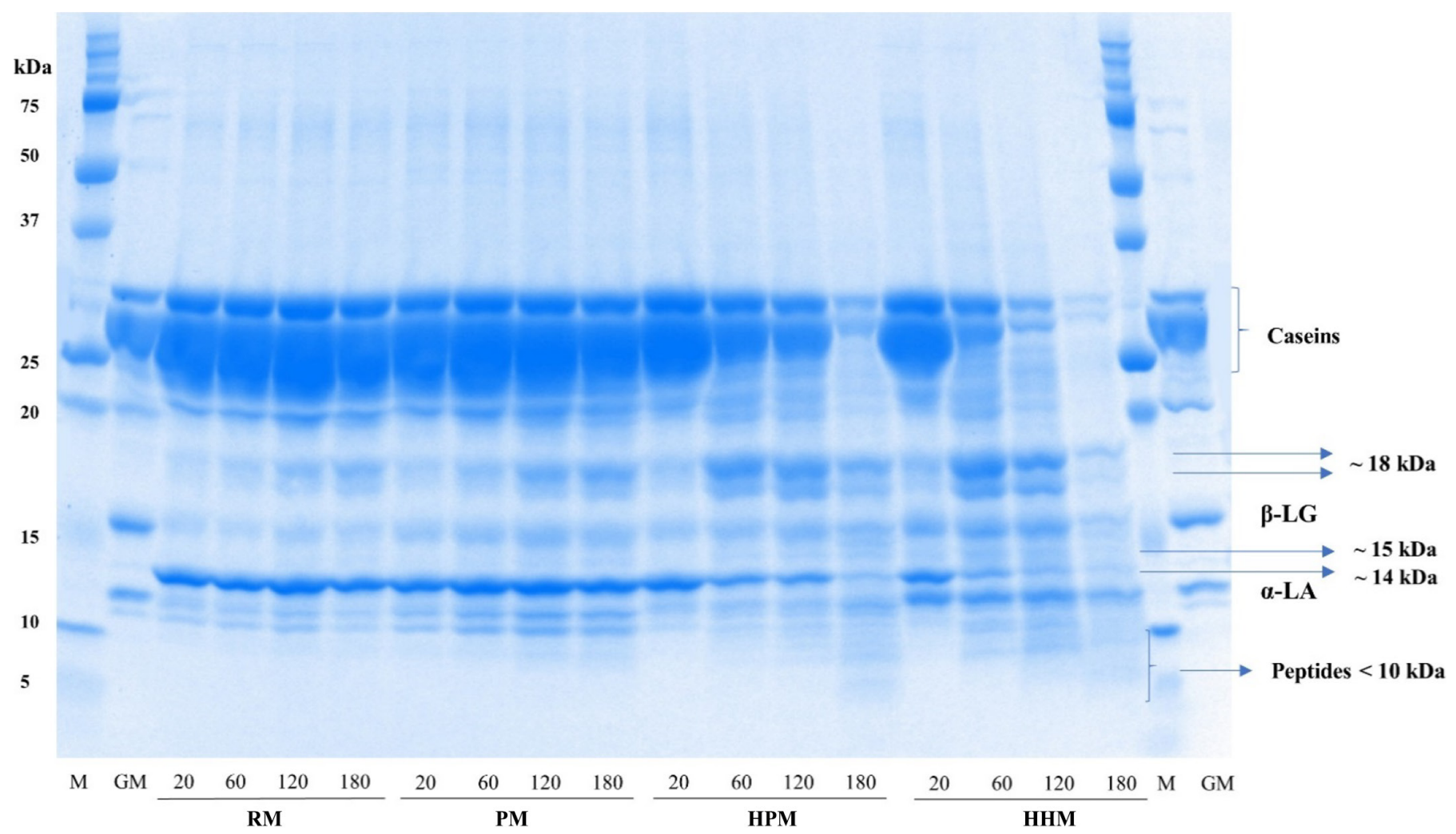

Figure 8. Sodium dodecyl sulfate-PAGE profiles of the gastric clots. M indicates molecular weight marker; GM indicates raw goat skim milk. $\mathrm{RM}=$ raw milk; $\mathrm{PM}=$ pasteurized milk $\left(75^{\circ} \mathrm{C}\right.$ for $\left.15 \mathrm{~s}\right) ; \mathrm{HPM}=$ homogenized pasteurized milk $\left(20\right.$ and $5 \mathrm{MPa}, 75^{\circ} \mathrm{C}$ for $\left.15 \mathrm{~s}\right) ; \mathrm{HHM}=$ homogenized heated milk ( 20 and $5 \mathrm{MPa}, 95^{\circ} \mathrm{C}$ for $5 \mathrm{~min}$ ). 

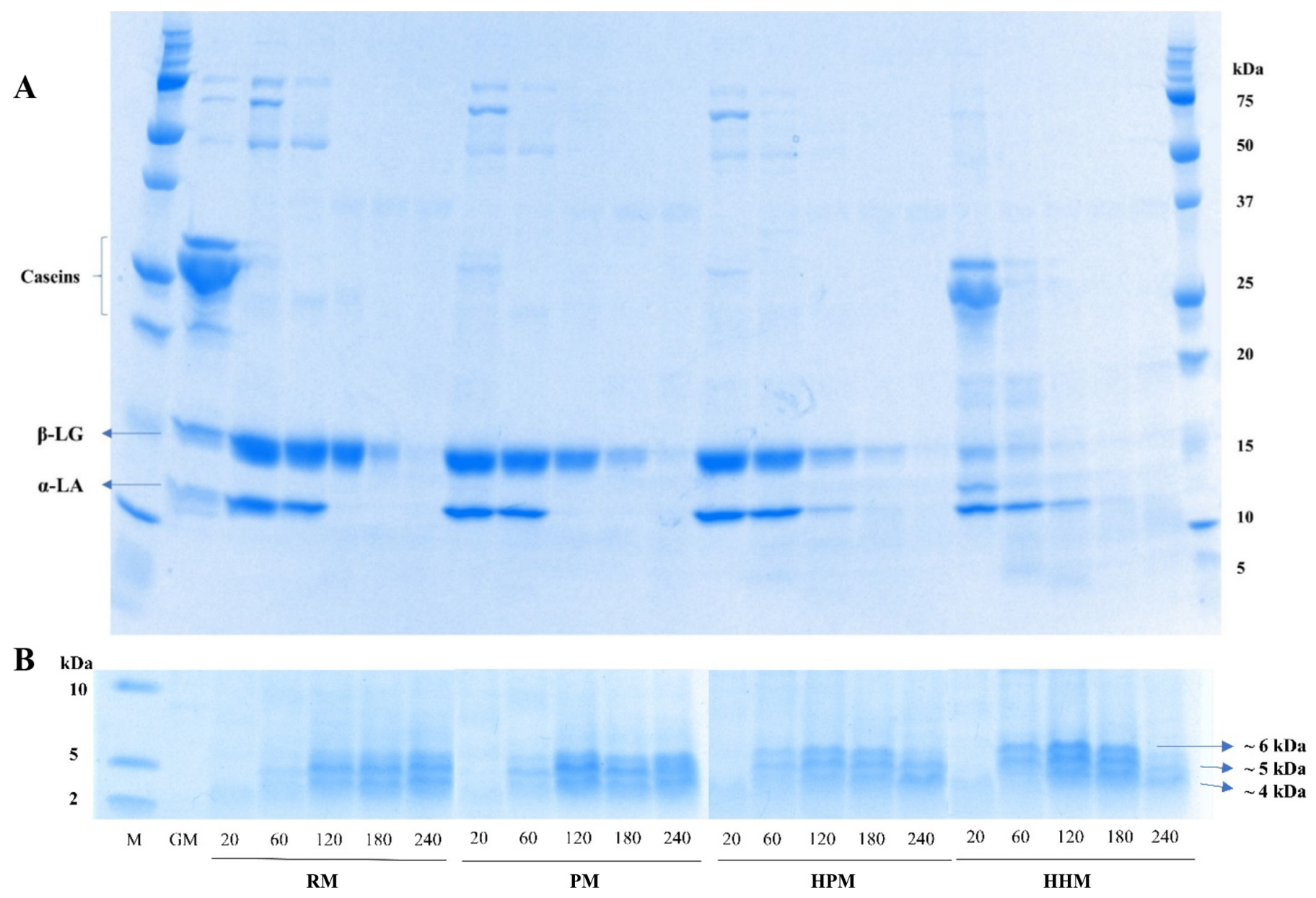

Figure 9. Sodium dodecyl sulfate-PAGE profiles of the emptied digesta, with emphasis on intact proteins (A, glycine SDS-PAGE) and peptides (B, tricine SDS-PAGE). M indicates molecular weight marker; GM indicates raw goat skim milk. RM $=$ raw milk; PM = pasteurized milk $\left(75^{\circ} \mathrm{C}\right.$ for $\left.15 \mathrm{~s}\right) ; \mathrm{HPM}=$ homogenized pasteurized milk $\left(20\right.$ and $5 \mathrm{MPa}, 75^{\circ} \mathrm{C}$ for $\left.15 \mathrm{~s}\right) ; \mathrm{HHM}=$ homogenized heated milk $(20$ and $5 \mathrm{MPa}$, $95^{\circ} \mathrm{C}$ for $\left.5 \mathrm{~min}\right)$.

of homogenization and heating on the $\mathrm{pH}$ profiles that we observed were similar to those previously reported for cow milk (Ye et al., 2016a, 2017), but the effect of homogenization appeared to be greater in the present study on goat milk.

\section{Gastric Destructuring and Emptying of Milk Components}

The highly fragmented structure of the homogenized goat milk clots probably contributed to their rapid digestion and emptying from the stomach, as indicated by the rapid decreases in clot weight (Figure 3) and the proportion of intact caseins in the clots (Figure 8). Fragmented clots would have a larger total surface area and would be more accessible to pepsin compared with the intact clots formed in the nonhomogenized goat milks. Adding to the accessibility to pepsin was the fact that the homogenization and heat treatments resulted in goat milk clots with more porous microstructures (Figure 2). In addition to enhancing the accessibility to pepsin digestion, the high degree of fragmentation of the homogenized goat milk clots would also lead to faster gastric emptying. It appeared that, after a certain stage of digestion, small clots formed in the homogenized milk could be emptied as particles through gastric sieving $(1 \mathrm{~mm})$, as shown in the photographs and confocal micrographs of the emptied digesta (Figures 5 and 6). Compared with homogenized cow milk clots (Ye et al., 2017), the DM of the homogenized goat milk clots decreased more rapidly during digestion (Figure 3B).

Interestingly, the small protein particles in the emptied digesta of the homogenized goat milks changed not only in their amounts but also in their apparent density [i.e., more floating particles were found in the digesta over time (Figure 6)]. This suggested a higher proportion of fat in the structure of the small protein 
particles during the later stages of digestion, which was supported by the simultaneous reddening of the particles in the digesta of HPM and HHM, as observed by confocal microscopy (Figure 5). Two factors may have led to this behavior. First, as proteins are digested by pepsin, homogenized fat globules may be able to remain in the clot structures and be released at a slower rate. As indicated by the SDS-PAGE profiles in the later stages of gastric digestion (Figures 8 and 9), the peptides formed during digestion appeared to be able to maintain the structure of the clots (Figure 2) and the emptied particles (Figure 5). They may have stabilized the fat globules in the clot structure as more intact caseins were digested, leading to increased proportions of fat in the clots (both the larger clots in the stomach and the smaller particles emptied with the digesta). Second, there may have been a $\mathrm{pH}$-induced association between the homogenized fat globules and the protein structures. Individual fat droplets were present in large amounts in the digesta of HPM and HHM at 20 and 60 min but had nearly disappeared from 120 min of digestion (Figure 5). The $\mathrm{pH}$ of the HPM and HHM digesta at 20,60 , and $120 \mathrm{~min}$ of digestion were around $\mathrm{pH} 6$, 5 , and 4-4.5, respectively (Figure 1). Milk fat globule membranes are disrupted during homogenization and the newly formed surfaces are covered by milk proteins, predominantly caseins. Denatured whey proteins are also involved in the surface layer when homogenization is followed by intense heat treatment. The pepsininduced clot formation occurred in the early stages of digestion when the $\mathrm{pH}$ was still fairly high $(\sim \mathrm{pH} 6)$. The decrease in $\mathrm{pH}$ near the isoelectric points of the milk proteins (4.6 for caseins, $\sim 5.2$ for $\beta$-LG; O'Mahony and Fox, 2013) during prolonged digestion probably promoted the active incorporation of protein-covered fat droplets into the protein structures. This could explain the disappearance of individually dispersed fat globules from 60 to 120 min of digestion when the $\mathrm{pH}$ of both the HPM and HHM digesta decreased to below 4.6 (Figure 1). This is supported by the confocal imaging of the emptied digesta of the nonhomogenized milks (Figure 5); protein aggregates started to associate with fat globules at $60 \mathrm{~min}$ of digestion $(\mathrm{pH}$ around 4.5) and became more abundant from $120 \mathrm{~min}$ when the $\mathrm{pH}$ decreased below 3.5. It was expected that the homogenized fat globules would associate with both large clots and the small protein particles in the emptied digesta. Both propositions discussed above would contribute to the increase in the fat-to-protein ratios from 120 to $180 \mathrm{~min}$ of digestion in both the clots (Figure 4) and the emptied digesta (Figure 7 ) of the homogenized goat milks.

The effects of processing on the structure and the breakdown of the goat milk clots also contributed to the differences in the dynamics of calcium release. The clotting of milk under gastric conditions occurs at around $\mathrm{pH} 6$, at which the colloidal calcium phosphate in the casein micelles is still largely insoluble (Dalgleish and Law, 1989). Compared with the RM clots, the rapid breakdown and emptying of the homogenized milk clots resulted in approximately $30 \%$ more milk calcium being released from the clots by 180 min of digestion (Figure $4 \mathrm{C})$.

\section{Protein Profiles and Proteolysis}

The SDS-PAGE results for the clots and the emptied digesta showed the effect of homogenization and heating on the protein digestion and the gastric emptying of goat milk. Pasteurization alone did not greatly affect protein digestion in the goat milk, as indicated by the similar SDS-PAGE profiles to those of raw goat milk. There were only marginal increases in the proportions of peptides in the clots and the digesta (Figures 8 and 9B). The protein profiles of the clots and the digesta during the digestion of the RM and PM were largely similar to those reported previously (Roy et al., 2021a,b). In contrast, the homogenized milks showed different protein profiles during digestion, particularly in the clots (Figure 8). The contents of intact caseins in both the HPM and HHM clots decreased rapidly during digestion and peptides made up a large proportion of the clot mass. This highlights the effect of homogenization on the formation and the breakdown of goat milk clots during gastric digestion.

Homogenization combined with heating at $95^{\circ} \mathrm{C}$ for 5 min resulted in 3 standout changes in the SDS-PAGE profiles. First, the HHM clots contained more whey proteins than the other clots (Figure 8); as reported for cow milk, heat-denatured whey proteins were incorporated into the clot structure (Ye et al., 2017). Second, the degradation of $\beta-\mathrm{LG}$ in the clots (Figure 8) and the digesta (Figure 9A) was most pronounced in HHM, followed by HPM. It is well known that the heat-induced denaturation and unfolding of $\beta-L G$ in milk promote their digestion by pepsin by exposing the cleavage sites (Barbé et al., 2013; Wang et al., 2018; van Lieshout et al., 2020; Aalaei et al., 2021). The HPM emptied digesta contained intermediate amounts of whey proteins, between those of the PM and HHM emptied digesta (Figure 9A). Similarly, Islam et al. (2017) reported that homogenization enhanced the proteolysis of $\beta-L G$ and $\alpha$-LA when digested ex vivo in human gastric juice. The disruption of the tertiary structure of whey proteins that is induced by homogenization (Qi et al., 2015) may enhance their accessibility to pepsin. Third, the intense heating of HHM also led to the emptying of a large amount of intact caseins at $20 \mathrm{~min}$ of digestion. These 
caseins were probably emptied in the form of small sedimenting protein particles, which were observed in the largest amounts in the HHM digesta (Figure 6). Heat-denatured whey proteins can be incorporated into the structure of pepsin-induced aggregates of casein micelles but they may disrupt the development of large clot structures by hindering the interactions between the casein micelles. As a result, the structure of the HHM clots was fine and loose (Figure 2) and many particles were small enough to be emptied early during digestion (Figure 6). The early emptying of intact caseins caused by homogenization and heat treatment has previously been demonstrated in cow milk (Ye et al., 2016a, 2017; Mulet-Cabero et al., 2019). Emptying of intact caseins caused by processing may affect the dynamics of protein hydrolysis during intestinal digestion.

$\alpha$-Lactalbumin was present in the first $60 \mathrm{~min}$ of digestion but had completely disappeared at $120 \mathrm{~min}$ in the RM and PM emptied digesta (Figure 9A), when the $\mathrm{pH}$ decreased from 4.5 to around 3.0 (Figure 1). This observation agreed with previous studies, which attributed it to the greater susceptibility of $\alpha$-LA to pepsin hydrolysis below $\mathrm{pH} 4$, when it undergoes a conformational change (Miranda et al., 1989; Mulet-Cabero et al., 2019; Roy et al., 2021a). The pH dependence of the hydrolysis of $\alpha$-LA by pepsin can explain the presence of $\alpha$-LA in the digesta of HPM and HHM at $120 \mathrm{~min}$ when the $\mathrm{pH}$ was still around 4.0.

The peptide profiles differed between the clots and the digesta (Figures 8 and 9). The digesta were rich in small peptides $(\leq 6 \mathrm{kDa})$, whereas the clots contained different peptides in a broader range of sizes. The distribution of peptides between the clots and the digesta may have been related to their difference in hydrophobicity. The hydrophobic peptides may have tended to associate with the clots, whereas the hydrophilic peptides may have readily entered the aqueous phase to be emptied. This is supported by the fact that the HHM digesta at $20 \mathrm{~min}$, in which a large amount of sedimenting protein particles was present, also contained the peptides at $\sim 14$ and $\sim 18 \mathrm{kDa}$. The peptide band at $\sim 14 \mathrm{kDa}$ that was abundant in the clots was probably the hydrophobic para-k-casein that is formed by the cleavage of $\kappa$-casein by pepsin (Figure 8). In agreement with the present study, Ye et al. (2016a) reported that para-k-casein was abundant in the clots of unheated cow milk during digestion but decreased in band intensity during the prolonged digestion of heated cow milk $\left(90^{\circ} \mathrm{C}\right.$ for $\left.20 \mathrm{~min}\right)$. Similar to para-k-casein, the 2 peptides at $\sim 18 \mathrm{kDa}$ in the clots of the homogenized goat milks also appeared to be early products of casein digestion that could be further hydrolyzed, as their concentrations decreased at 180 min of diges- tion (Figure 8). Further peptide analysis will better elucidate the characteristics of the peptides and their distribution between the clots and the emptied digesta.

\section{CONCLUSIONS}

Pasteurization did not greatly affect the digestion of goat milk, whereas homogenization had marked effects, including delaying the reduction in $\mathrm{pH}$ and resulting in the formation of fragmented gastric clots that released calcium more rapidly, showed greater extents of proteolysis, and were emptied more rapidly. The emptied digesta of the homogenized goat milks also contained small protein particles that varied not only in their amounts but also in their apparent densities during digestion. There may have been a shift in the location of the homogenized fat globules as the $\mathrm{pH}$ changed, which affected the density of the emptied protein particles and the compositions of the clots and the emptied digesta. Homogenization combined with heat treatment at $95^{\circ} \mathrm{C}$ for 5 min resulted in the incorporation of whey proteins into the gastric clots, the rapid hydrolysis of $\beta-\mathrm{LG}$, and the emptying of intact caseins in the early stages of digestion. Overall, homogenization together with heat treatment had similar effects on the gastric digestion behavior of goat milk to that of cow milk, as reported previously, whereas homogenization had a greater effect on the gastric digestion of goat milk.

\section{ACKNOWLEDGMENTS}

This work was supported by the New Zealand Ministry of Business, Innovation, and Employment (research program "New Zealand Milks Mean More") and the Riddet Institute, a New Zealand Centre of Research Excellence (CoRE) funded by the Tertiary Education Commission (Wellington, New Zealand). The authors thank Cilantro Cheese Ltd. (Hamilton, New Zealand) for providing fresh goat milk. The authors thank Xianqian Zhu and Sihan Ma (Riddet Institute, Palmerston North, New Zealand) for performing confocal imaging. The authors acknowledge Marita Broadhurst and Mike Weeks (AgResearch, New Zealand) for their contributions to the logistics and the compositional analyses. Manawatu Microscopy and Imaging Centre (Palmerston North, New Zealand) is acknowledged for accommodating confocal imaging. The authors thank Claire Woodhall for proofreading the manuscript. The authors have not stated any conflicts of interest.

\section{REFERENCES}

Aalaei, K., B. Khakimov, C. De Gobba, and L. Ahrné. 2021. Digestion patterns of proteins in pasteurized and ultra-high temperature 
milk using in vitro gastric models of adult and elderly. J. Food Eng. 292:110305. https://doi.org/10.1016/j.jfoodeng.2020.110305.

Ambrosoli, R., L. di Stasio, and P. Mazzocco. 1988. Content of $\alpha_{\mathrm{S}^{-}}$ casein and coagulation properties in goat milk. J. Dairy Sci. 71:2428. https://doi.org/10.3168/jds.S0022-0302(88)79520-X.

AOAC International. 2016. Official Methods of Analysis. 20th ed. AOAC International.

Barbé, F., O. Ménard, Y. Le Gouar, C. Buffière, M. H. Famelart, B. Laroche, S. Le Feunteun, D. Dupont, and D. Rémond. 2013. The heat treatment and the gelation are strong determinants of the kinetics of milk proteins digestion and of the peripheral availability of amino acids. Food Chem. 136:1203-1212. https://doi.org/10 .1016/j.foodchem.2012.09.022.

Brodkorb, A., L. Egger, M. Alminger, P. Alvito, R. Assunção, S. Ballance, T. Bohn, C. Bourlieu-Lacanal, R. Boutrou, F. Carrière, A. Clemente, M. Corredig, D. Dupont, C. Dufour, C. Edwards, M. Golding, S. Karakaya, B. Kirkhus, S. Le Feunteun, U. Lesmes, A. Macierzanka, A. R. Mackie, C. Martins, S. Marze, D. J. McClements, O. Ménard, M. Minekus, R. Portmann, C. N. Santos, I. Souchon, R. P. Singh, G. E. Vegarud, M. S. J. Wickham, W. Weitschies, and I. Recio. 2019. INFOGEST static in vitro simulation of gastrointestinal food digestion. Nat. Protoc. 14:991-1014. https://doi.org/10.1038/s41596-018-0119-1.

Claeys, W. L., C. Verraes, S. Cardoen, J. De Block, A. Huyghebaert, K. Raes, K. Dewettinck, and L. Herman. 2014. Consumption of raw or heated milk from different species: An evaluation of the nutritional and potential health benefits. Food Control 42:188-201. https://doi.org/10.1016/j.foodcont.2014.01.045.

Clark, S., and M. B. Mora García. 2017. A 100-year review: Advances in goat milk research. J. Dairy Sci. 100:10026-10044. https://doi .org/10.3168/jds.2017-13287.

Dalgleish, D. G., and A. J. R. Law. 1989. pH-induced dissociation of bovine casein micelles II. Mineral solubilization and its relation to casein release. J. Dairy Res. 56:727-735. https://doi.org/10.1017/ S0022029900029290.

FAOSTAT. 2021. Food and Agriculture Data. Accessed Mar. 5, 2021. http://www.fao.org/faostat/en/\#data.

Haenlein, G. F. W. 2004. Goat milk in human nutrition. Small Rumin. Res. 51:155-163. https://doi.org/10.1016/j.smallrumres.2003 .08 .010 .

Haider, S. R., H. J. Reid, and B. L. Sharp. 2012. Tricine-SDS-PAGE. Methods Mol. Biol. 869:81-91. https://doi.org/10.1007/978-1 $-61779-821-4$

Hodgkinson, A. J., O. A. M. Wallace, I. Boggs, M. Broadhurst, and C. G. Prosser. 2018. Gastric digestion of cow and goat milk: impact of infant and young child in vitro digestion conditions. Food Chem. 245:275-281. https://doi.org/10.1016/j.foodchem.2017.10.028.

Huppertz, T., and L. W. Chia. 2021. Milk protein coagulation under gastric conditions: A review. Int. Dairy J. 113:104882. https://doi .org/10.1016/j.idairyj.2020.104882.

Islam, M. A., H. Devle, I. Comi, E. K. Ulleberg, E. O. Rukke, G. E. Vegarud, and D. Ekeberg. 2017. Ex vivo digestion of raw, pasteurised and homogenised milk - Effects on lipolysis and proteolysis. Int. Dairy J. 65:14-19. https://doi.org/10.1016/j.idairyj.2016.09 .008 .

Kong, F., and R. P. Singh. 2010. A human gastric simulator (HGS) to study food digestion in human stomach. J. Food Sci. 75:E627E635. https://doi.org/10.1111/j.1750-3841.2010.01856.x.

Li, S., A. Ye, and H. Singh. 2019. Seasonal variations in composition, properties, and heat-induced changes in bovine milk in a seasonal calving system. J. Dairy Sci. 102:7747-7759. https://doi.org/10 $.3168 /$ jds.2019-16685.

Li, S., A. Ye, and H. Singh. 2021. Impacts of heat-induced changes on milk protein digestibility: A review. Int. Dairy J. 123:105160. https://doi.org/10.1016/j.idairyj.2021.105160.

Maathuis, A., R. Havenaar, T. He, and S. Bellmann. 2017. Protein digestion and quality of goat and cow milk infant formula and human milk under simulated infant conditions. J. Pediatr. Gastroenterol. Nutr. 65:661-666. https://doi.org/10.1097/MPG .0000000000001740 .
Miranda, G., G. Hazé, P. Scanff, and J. P. Pélissier. 1989. Hydrolysis of $\alpha$-lactalbumin by chymosin and pepsin. Effect of conformation and pH. Lait 69:451-459. https://doi.org/10.1051/lait:1989630.

Miranda, G., and J.-P. Pelissier. 1987. Influence of heat treatment of bovine skim-milk on in vivo digestion in rat stomach. Lait 67:365377. https://doi.org/10.1051/lait:1987321.

Mulet-Cabero, A. I., L. Egger, R. Portmann, O. Ménard, S. Marze, M. Minekus, S. Le Feunteun, A. Sarkar, M. M. L. Grundy, F. Carrière, M. Golding, D. Dupont, I. Recio, A. Brodkorb, and A. Mackie. 2020a. A standardised semi-dynamic in vitro digestion method suitable for food - An international consensus. Food Funct. 11:1702-1720. https://doi.org/10.1039/C9FO01293A.

Mulet-Cabero, A. I., A. R. Mackie, A. Brodkorb, and P. J. Wilde. 2020b. Dairy structures and physiological responses: A matter of gastric digestion. Crit. Rev. Food Sci. Nutr. 60:3737-3752. https:/ /doi.org/10.1080/10408398.2019.1707159.

Mulet-Cabero, A. I., A. R. Mackie, P. J. Wilde, M. A. Fenelon, and A. Brodkorb. 2019. Structural mechanism and kinetics of in vitro gastric digestion are affected by process-induced changes in bovine milk. Food Hydrocoll. 86:172-183. https://doi.org/10.1016/ j.foodhyd.2018.03.035.

O'Mahony, J. A., and P. F. Fox. 2013. Milk proteins: Introduction and historical aspects. Pages 43-85 in Advanced Dairy Chemistry. P. L. H. McSweeney and P. F. Fox, ed. Springer.

Park, Y. W., M. Juárez, M. Ramos, and G. F. W. Haenlein. 2007. Physico-chemical characteristics of goat and sheep milk. Small Rumin. Res. 68:88-113. https://doi.org/10.1016/j.smallrumres.2006 .09 .013 .

Pesic, M. B., M. B. Barac, S. P. Stanojevic, N. M. Ristic, O. D. Macej, and M. M. Vrvic. 2012. Heat induced casein-whey protein interactions at natural $\mathrm{pH}$ of milk: A comparison between caprine and bovine milk. Small Rumin. Res. 108:77-86. https://doi.org/10.1016/j .smallrumres.2012.06.013.

Pulina, G., M. J. Milán, M. P. Lavín, A. Theodoridis, E. Morin, J. Capote, D. L. Thomas, A. H. D. Francesconi, and G. Caja. 2018. Invited review: Current production trends, farm structures, and economics of the dairy sheep and goat sectors. J. Dairy Sci. 101:6715-6729. https://doi.org/10.3168/jds.2017-14015.

Qi, P. X., D. Ren, Y. Xiao, and P. M. Tomasula. 2015. Effect of homogenization and pasteurization on the structure and stability of whey protein in milk. J. Dairy Sci. 98:2884-2897. https://doi.org/ 10.3168/jds.2014-8920.

Roy, D., A. Ye, P. J. Moughan, and H. Singh. 2020. Composition, structure, and digestive dynamics of milk from different speciesA review. Front. Nutr. 7:577759. https://doi.org/10.3389/fnut .2020.577759.

Roy, D., A. Ye, P. J. Moughan, and H. Singh. 2021a. Structural changes in cow, goat, and sheep skim milk during dynamic in vitro gastric digestion. J. Dairy Sci. 104:1394-1411. https://doi.org/10 .3168/jds.2020-18779.

Roy, D., A. Ye, P. J. Moughan, and H. Singh. 2021b. Impact of gastric coagulation on the kinetics of release of fat globules from milk of different species. Food Funct. 12:1783-1802. https://doi.org/10 $.1039 /$ D0FO02870C.

Salaün, F., B. Mietton, and F. Gaucheron. 2005. Buffering capacity of dairy products. Int. Dairy J. 15:95-109. https://doi.org/10.1016/ j.idairyj.2004.06.007.

Schägger, H. 2006. Tricine-SDS-PAGE. Nat. Protoc. 1:16-22. https:/ /doi.org/10.1038/nprot.2006.4.

Sharma, R., H. Singh, and M. W. Taylor. 1996. Composition and structure of fat globule surface layers in recombined milk. J. Food Sci. 61:28-32. https://doi.org/10.1111/j.1365-2621.1996.tb14719 .x.

van Lieshout, G. A. A., T. T. Lambers, M. C. E. Bragt, and K. A. Hettinga. 2020. How processing may affect milk protein digestion and overall physiological outcomes: A systematic review. Crit. Rev. Food Sci. Nutr. 60:2422-2445. https://doi.org/10.1080/10408398 .2019.1646703.

Verruck, S., A. Dantas, and E. S. Prudencio. 2019. Functionality of the components from goat's milk, recent advances for functional 
dairy products development and its implications on human health. J. Funct. Foods 52:243-257. https://doi.org/10.1016/j.jff.2018.11 .017 .

Wada, Y., and B. Lönnerdal. 2014. Effects of different industrial heating processes of milk on site-specific protein modifications and their relationship to in vitro and in vivo digestibility. J. Agric. Food Chem. 62:4175-4185. https://doi.org/10.1021/jf501617s.

Wang, X., A. Ye, Q. Lin, J. Han, and H. Singh. 2018. Gastric digestion of milk protein ingredients: Study using an in vitro dynamic model. J. Dairy Sci. 101:6842-6852. https://doi.org/10.3168/jds .2017-14284.

Wang, Y., B. Eastwood, Z. Yang, L. de Campo, R. Knott, C. Prosser, E. Carpenter, and Y. Hemar. 2019. Rheological and structural characterization of acidified skim milks and infant formulae made from cow and goat milk. Food Hydrocoll. 96:161-170. https://doi .org/10.1016/j.foodhyd.2019.05.020.

Ye, A. 2021. Gastric colloidal behaviour of milk protein as a tool for manipulating nutrient digestion in dairy products and protein emulsions. Food Hydrocoll. 115:106599. https://doi.org/10.1016/j .foodhyd.2021.106599.

Ye, A., J. Cui, E. Carpenter, C. Prosser, and H. Singh. 2019a. Dynamic in vitro gastric digestion of infant formulae made with goat milk and cow milk: Influence of protein composition. Int. Dairy J. 97:76-85. https://doi.org/10.1016/j.idairyj.2019.06.002.

Ye, A., J. Cui, D. Dalgleish, and H. Singh. 2016a. The formation and breakdown of structured clots from whole milk during gas- tric digestion. Food Funct. 7:4259-4266. https://doi.org/10.1039/ C6FO00228E.

Ye, A., J. Cui, D. Dalgleish, and H. Singh. 2016b. Formation of a structured clot during the gastric digestion of milk: impact on the rate of protein hydrolysis. Food Hydrocoll. 52:478-486. https://doi .org/10.1016/j.foodhyd.2015.07.023.

Ye, A., J. Cui, D. Dalgleish, and H. Singh. 2017. Effect of homogenization and heat treatment on the behavior of protein and fat globules during gastric digestion of milk. J. Dairy Sci. 100:36-47. https://doi.org/10.3168/jds.2016-11764.

Ye, A., W. Liu, J. Cui, X. Kong, D. Roy, Y. Kong, J. Han, and H. Singh. 2019b. Coagulation behaviour of milk under gastric digestion: Effect of pasteurization and ultra-high temperature treatment. Food Chem. 286:216-225. https://doi.org/10.1016/j .foodchem.2019.02.010.

\section{ORCIDS}

Siqi Li $\odot$ https://orcid.org/0000-0003-4971-9705

Aiqian Ye ๑ https://orcid.org/0000-0003-1048-8858

Zheng Pan @ https://orcid.org/0000-0002-9208-8358

Harjinder Singh (๑) https://orcid.org/0000-0002-8807-3241 